\title{
Inhaled Corticosteroids in COPD: A Controversy
}

\author{
Peter J. Barnes \\ National Heart and Lung Institute, Imperial College, London, UK
}

\section{Key Words}

Chronic obstructive pulmonary disease $\cdot$ Corticosteroids, inhaled $\cdot$ Long-acting $\beta_{2}$-agonist

\begin{abstract}
Inhaled corticosteroids (ICS) are now very widely used in high doses in the management of COPD patients. In sharp contrast to the situation in asthma, ICS provide little or no benefit in COPD patients and may have long-term detrimental effects. High doses of ICS fail to reduce disease progression or mortality, even when combined with a long-acting $\beta_{2}$-agonist (LABA). Several trials have demonstrated that ICS reduce exacerbations by $20-25 \%$, particularly in patients with more severe disease, but these studies are confounded by poor trial design and more appropriate analysis shows no benefit. Indeed, the benefit of combination inhalers seems to be largely due to the effect of the LABA, and long-acting bronchodilators - including tiotropium - provide similar benefits in reducing exacerbations. However, there may be some COPD patients, for example those with concomitant asthma, who benefit from ICS. Yet it has not been possible to identify any clinical factors that predict corticosteroid responsiveness in COPD patients in the large clinical trials. There is increasing evidence that high doses of ICS may have detrimental effects on bones and may increase the risk of pneumonia. ICS fail to suppress inflammation in COPD pa-
\end{abstract}

tients because there is a marked reduction in histone deacetylase-2, the nuclear enzyme that corticosteroids require to switch off activated inflammatory genes. In the future, alternative anti-inflammatory treatments will be needed for COPD or therapeutic strategies which reverse the molecular pathways that causes corticosteroid resistance.

Copyright $\odot 2010$ S. Karger AG, Basel

\section{Introduction}

Inhaled corticosteroids (ICS) are highly effective in asthma and have become the mainstay of therapy in all patients with persistent symptoms [1]. This reflects the fact that asthma is associated with a chronic inflammation of the airways that is readily suppressed by low doses of corticosteroids in most patients [2]. In sharp contrast, corticosteroids are poorly effective in most patients with COPD, even when high oral or inhaled doses are used. Patients with COPD are commonly treated as if they have asthma and many patients with a diagnosis of COPD are now treated with high doses of ICS, often in

Previous article in this series: 1. Suissa S: Co-morbidity in COPD: the effects of cardiovascular drug therapies. Respiration 2010;80:3-7.

\section{KARGER \\ Fax +4161306 1234 \\ E-Mail karger@karger.ch}

www.karger.com
(C) 2010 S. Karger AG, Basel

$0025-7931 / 10 / 0802-0089 \$ 26.00 / 0$

Accessible online at:

www.karger.com/res
Prof. P.J. Barnes

Section of Airway Disease

National Heart and Lung Institute

Dovehouse St., London SW3 6LY (UK)

Tel. +44 207351 8174, Fax +44 207351 5675, E-Mail p.j.barnes@imperial.ac.uk 
combination with a long-acting $\beta_{2}$-agonist (LABA) as a fixed combination (fluticasone/salmeterol or budesonide/ formoterol). Over $70 \%$ of patients with diagnosed COPD are now treated with high doses of ICS as a result of successful marketing, yet there is still little evidence for their clinical benefit, and increasing evidence that the high doses currently recommended are harmful and costly [3, 4]. ICS are recommended in currently used management guidelines for COPD; for example, the GOLD Guideline suggests that inhaled corticosteroids should be introduced only in patients with severe disease $\left(\mathrm{FEV}_{1}<50 \%\right.$ predicted normal, GOLD stage III) who have two or more exacerbations a year [5]. It is likely that this would amount to less than $20 \%$ of all patients, rather than the more than $70 \%$ currently prescribed this therapy, suggesting that ICS are grossly overprescribed. Indeed, the question is whether they should be used at all, unless patients have concomitant asthma [4].

\section{Clinical Trials with ICS}

Many placebo-controlled clinical trials have been conducted with ICS in patients with differing severities of COPD. The first relatively small study showed no effect of high-dose ICS on $\mathrm{FEV}_{1}$ decline in COPD patients over 2 years and no effect on exacerbations, although the study was underpowered to measure this [6]. A second study showed no clinical benefit of high dose ICS over 6 months [7]. Four large studies then looked at high doses of ICS compared to a placebo over a 3-year period and all showed no effect on disease progression, measured by annual decline in $\mathrm{FEV}_{1}$, which was the primary outcome measurement of these studies [8-11]. However, there was a reduction in the number of exacerbations, a secondary outcome measure, in two of the studies, although there were differences in how exacerbations were defined. An earlier study specifically looked at exacerbations of COPD and showed that high-dose ICS had no overall effect on exacerbations, but a post-hoc analysis showed a reduction in severe exacerbations [12]. Even putting all these studies together in a meta-analysis failed to show any effect on $\mathrm{FEV}_{1}$ decline [13], although another metaanalysis of the same data apparently showed a small reduction in disease progression [14]. None of these studies was sufficiently powered to look at mortality, but pooled analysis of several trials comprising over 5,000 patients suggested that there was a reduction in all-cause mortality of approximately $25 \%$ [15]. In the large TORCH study including approximately 6,000 patients with COPD studied over 3 years, in which all-cause mortality was the primary outcome measure, there was no evidence that high-dose fluticasone alone reduced mortality - in fact there was a small increase $(\sim 6 \%)$ in mortality by the end of the study, although this was not statistically significant [16]. A post-hoc analysis of the TORCH study showed that ICS has a small but statistically significant effect in reducing the annual rate in $\mathrm{FEV}_{1}$ decline [17]. Taking all the studies together, a meta-analysis, which included over 13,000 COPD patients, found no significant effect if ICS on rate of $\mathrm{FEV}_{1}$ decline or on mortality, although exacerbations were reduced by approximately $25 \%[18]$.

\section{LABA/ICS Combination Studies}

More recently, the effects of fluticasone/salmeterol and budesonide/formoterol combination inhalers have been studied, but these studies are often difficult to interpret as it is difficult to disentangle the effect of the long-acting bronchodilator from the effect of the corticosteroid. These trials showed beneficial effects of the combination inhaler, but the effects of the ICS alone when used as a comparator were less marked or absent $[16,19-24]$. Combination inhalers consistently reduce exacerbations by $20-25 \%$, which is similar in magnitude to the effects of long-acting bronchodilators (LABA or tiotropium) alone. The largest of these studies, the TORCH study, showed a reduction in all cause mortality with fluticasone/salmeterol, which did not quite reach statistical significance $(\mathrm{p}=0.052)$. A meta-analysis, which included the TORCH data, found no effect of combination inhalers on mortality, however [25]. Taken together, these data provide little evidence that ICS reduce disease progression or mortality, even when combined with LABA. However, there is a consistent reduction in exacerbations and hospitalisations, similar in magnitude to that seen with lung acting bronchodilators such as LABA and tiotropium. Indeed, a direct comparison of fluticasone/salmeterol and tiotropium in COPD patients showed no statistical difference in exacerbation rates over 2 years [26].

\section{Misinterpretation of the ICS Trials}

Suissa et al. [27] have identified several shortcomings in the randomised controlled studies of ICS in COPD patients. A major limitation of these studies was the re- 
quirement that patients should stop using their prescribed ICS at the time of randomisation, so that a large proportion of patients in the placebo or comparator arms were abruptly withdrawn from a high dose of ICS. A detailed re-analysis of one such trial showed that the effect of ICS on the likelihood of the first exacerbation was significantly protective only among patients who were previously treated with ICS but had to discontinue [27]. Furthermore, it showed no effect of ICS in patients who were naïve to ICS prior to randomisation. Thus, trials that have reported a benefit for ICS may have simply shown an effect of abruptly discontinuing high dose ICS therapy, which may lead to side-effects, such as relative adrenal insufficiency and other rebound steroid effects, since there are clear systemic effects with high doses of ICS such as fluticasone propionate.

Another problem that was identified was the incomplete follow-up of patients, who were observed only until they discontinued the study drug, rather than to the end of planned follow-up. This is a major problem in view of the high and early rates of discontinuation in these studies. This bias was demonstrated in studies with incomplete follow-up that found a $\sim 25 \%$ reduction in all-cause mortality with ICS [15], which was not confirmed in the TORCH trial, in which all patients were followed for 3 years to identify all deaths using a proper intent-to-treat analysis [16]. The OPTIMAL trial, which also avoided this bias by identifying exacerbations, the primary outcome, for the entire one-year follow-up period also found no benefit of ICS [24].

Measurement of $\mathrm{FEV}_{1}$ decline was also misinterpreted due to failure of intention-to-treat analysis. In the TORCH study, nearly $18 \%$ of placebo patients did not contribute a single $\mathrm{FEV}_{1}$ value to the analysis of $\mathrm{FEV}_{1}$ decline, compared with only $9 \%$ of patients allocated to combination therapy [17]. The excluded patients are likely to have had the lowest $\mathrm{FEV}_{1}$ values at their initial visit, so that the slope of $\mathrm{FEV}_{1}$ decline in the remaining patients with better $\mathrm{FEV}_{1}$ initial values at the first visit may have been affected by regression to the mean, thus giving the impression that ICS affect $\mathrm{FEV}_{1}$ decline [28].

As discussed above, an important issue with combination therapy in COPD patients relates to the effect of each component. A $2 \times 2$ factorial study analysis of the TORCH trial data to measure the independent contribution of the LABA and the ICS found that the reduction in mortality was entirely explained by the salmeterol component and none could be attributable to the ICS [27, 29].

Finally, observational studies that have suggested a reduction in mortality with ICS use were all flawed with 'immortal time bias' as there was a survival advantage to the ICS users by defining exposure in such a way that they had to be alive to receive their ICS prescription [30]. Indeed, a correct analysis of the data completely eliminated any apparent protective effect of ICS [31].

\section{Are There Any COPD Patients Who May Benefit from ICS?}

COPD is a heterogeneous disease with several different pathological mechanisms, including emphysema, small airway disease and mucous hypersecretion, so it is possible that corticosteroids might work more effectively on some components of disease compared to others. However, this has so far not been investigated or proven in clinical trials. COPD patients who have some of the clinical features of asthma, with greater reversibility of airways obstruction, may have increased sputum eosinophils and an increase in exhaled nitric oxide concentration, which are characteristics of asthmatic airway inflammation [32]. These COPD patients probably have coexistent asthma. COPD patients with increased sputum eosinophils show a reduction in sputum eosinophils with oral steroids [33] and a management strategy that increased ICS dose or added oral steroids with increased sputum eosinophils reduced exacerbations, as had previously been observed in patients with asthma [34]. A metaanalysis of over 13,000 COPD patients failed to identify any clinical factors that were associated with better responsiveness to ICS [18].

\section{Adverse Effects of ICS in COPD Patients}

ICS, especially in high doses, may cause oral candidiasis and hoarseness, and these local side effects are increased in COPD patients on ICS [18]. High doses of ICS are well known to have systemic effects due to lung absorption. Elderly patients with COPD who have poor mobility and nutrition, who smoke and have co-morbid diseases, such as ischaemic heart disease and diabetes, may be at greater risk of developing corticosteroid side effects, but these may take time to develop and this may be longer than the duration of a clinical trial, even over a 3-year period. Even low doses of ICS are associated with increased risk of cataracts in elderly patients [35]. There is a dose-related increase in the risk of fractures with use of ICS amongst elderly patients in the community [36]. Patients with COPD may be at even greater risk as COPD 
itself is associated with osteoporosis, and cigarette smoking, immobility and poor nutrition are additional risk factors $[37,38]$. In the Lung Health Study lumbar and hip bone density was reduced in the patients treated with inhaled triamcinolone but there was no increase in fractures [39]. However, in the TORCH study, although there was a high incidence of osteoporosis amongst COPD patients, there was no detrimental effect of ICS on bone mineral density or on fracture rate [40].

Recently, several large studies have shown that ICS (alone or in combination) are associated with a significant increase in risk of pneumonia, although this has not been well characterized [23, 26, 41]. This has been confirmed in a population-based study of over 175,000 COPD patients with hospital-diagnosed pneumonia, where there was a clear dose-related risk [42]. The increased risk of pneumonia with ICS has also been confirmed in meta-analyses, which have also identified an increased risk of death from pneumonia [18, 43, 44]. This increased risk of pneumonia with ICS may reflect the increased susceptibility of COPD patients to bacterial infections as a result of impaired mucosal innate immunity in the lungs. More studies are needed to define the pneumonia, the dose-relationship to ICS and whether there are differences between different corticosteroids.

\section{Why Do ICS Not Work in COPD?}

There are now good scientific reasons why even high doses of ICS fail to reduce inflammation in COPD patients. This corticosteroid-resistance has been demonstrated by the failure of high doses of ICS to reduce inflammatory markers in sputum or bronchial biopsies of COPD patients [45-49]. The reason why ICS fail to suppress inflammation cannot be explained by impaired access of the inhaled drug to sites of inflammation as an oral corticosteroid is equally ineffective [45].

The reason for the extreme corticosteroid resistance in COPD may be due to a marked reduction in the nuclear enzyme histone deacetylase-2 (HDAC2), which is required for corticosteroids to switch off activated inflammatory genes that are associated with histone acetylation [50-52]. This molecular mechanism involves HDAC2 deacetylating acetylated glucocorticoid receptors to allow them to suppress nuclear factor- $\kappa \mathrm{B}(\mathrm{NF}-\kappa \mathrm{B})$-activated inflammatory genes [53]. The reduction in HDAC2 activity and expression appears to be secondary to oxidative stress through the formation of peroxynitrite, which nitrates certain critical tyrosine resides on HDAC2, leading to ubiquitination and destruction by the proteasome $[54,55]$. In addition, oxidative stress activates phosphoinositide-3-kinase- $\delta$ (PI3K $\delta$ ), which also results in inactivation of HDAC2 [56]. The corticosteroid resistance persists even after smoking cessation, as the inflammatory response and oxidative stress continue [57, 58] and HDAC2 is just as reduced in ex-smokers as in smokers [51]. In asthmatics who smoke there is a marked reduction in responsiveness to corticosteroids [59] and this may also be explained by the oxidative stress of cigarette smoking reducing the anti-inflammatory effects of corticosteroids through a similar molecular mechanism involving HDAC2 [60].

\section{What Is the Way Forward?}

Corticosteroid resistance in COPD is a major clinical problem in COPD patients at all stages of the disease [61]. It cannot be overcome by increasing the dose of ICS or by oral corticosteroids, and systemic side effects at these high doses are problematic. There are two possible approaches. The first is to develop alternative anti-inflammatory treatments, such as phosphodiesterase- 4 inhibitors, p38 mitogen-activated protein kinase inhibitors or NF- $\mathrm{KB}$ inhibitors, which suppress inflammatory genes independently of HDAC2 [62]. These treatments all have a high risk of side effects after systemic administration so that inhaled delivery may be needed with drugs that are retained within the lung. The alternative approach is the reverse corticosteroid resistance by restoring HDAC2 activity and levels to normal. This can be achieved in vitro by viral plasmid transfer of HDAC2 [53], but gene transfer is unlikely to be a useful therapeutic approach. The same effect may be achieved with low concentrations of theophylline in vitro, particularly when HDAC2 is reduced by oxidative stress [63-65]. Similar effects are also seen in smoking mice in vivo [66] and in COPD patients [Ford et al., unpubl. data]. Low doses of theophylline also improve recovery from a COPD exacerbation and this is associated with an increase in HDAC activity [67]. Furthermore, low dose theophylline combined with ICS is more effective than either drug alone in improving lung function in smoking asthmatics [68]. The molecular mechanisms of action of theophylline in restoring HDAC2 activity and steroid responsiveness are currently being elucidated, but it seems that theophylline may achieve this by directly inhibiting oxidant-activated PI $3 \mathrm{~K} \delta$ and its effects 
are mimicked by selective PI3K $\delta$ inhibitors and by knocking out the PI3K $\delta$ gene in mice [56]. Theophylline is cheap and available and when used in low doses (giving plasma concentrations of $1-5 \mathrm{mg} / \mathrm{l}$ ) does not cause significant side effects. This therapy should be investigated in patients with COPD in long-term studies using important clinical outcomes, such as disease progression, exacerbations and mortality.
There are other strategies for reversing corticosteroid resistance in COPD, including more potent antioxidants and peroxynitrite scavengers [69]. Other drugs may inhibit the signalling pathways that lead to reduced HDAC2, including existing treatments such as macrolides $[61,70]$. In the future novel activators of HDAC2 may be developed [71].

\section{References}

$>1$ Bateman ED, Hurd SS, Barnes PJ, Bousquet J, Drazen JM, Fitzgerald M, Gibson P, Ohta K, O’Byrne P, Pedersen SE, Pizzichini E, Sullivan SD, Wenzel SE, Zar HJ: Global strategy for asthma management and prevention: GINA executive summary. Eur Respir J 2008;31:143-178.

$>2$ Barnes PJ: How corticosteroids control inflammation. Br J Pharmacol 2006;148:245254.

$\checkmark 3$ Barnes PJ: Inhaled corticosteroids are not helpful in chronic obstructive pulmonary disease. Am J Resp Crit Care Med 2000;161: 342-344.

4 Suissa S, Barnes PJ: Inhaled corticosteroids in COPD: the case against. Eur Respir J 2009; 34:13-16.

$\checkmark 5$ Rabe KF, Hurd S, Anzueto A, Barnes PJ, Buist SA, Calverley P, Fukuchi Y, Jenkins C, Rodriguez-Roisin R, van Weel C, Zielinski J: Global strategy for the diagnosis, management, and prevention of COPD: $2006 \mathrm{Up}$ date. Am J Respir Crit Care Med. 2007;176: 532-555.

6 Renkema TE, Schouten JP, Koeter GH, Postma DS: Effects of long-term treatment with corticosteroids in COPD. Chest 1996;109: 1156-1162.

7 Bourbeau J, Rouleau MY, Boucher S: Randomised controlled trial of inhaled corticosteroids in patients with chronic obstructive pulmonary disease. Thorax 1998;53:477482.

$>8$ Vestbo J, Sorensen T, Lange P, Brix A, Torre P, Viskum K: Long-term effect of inhaled budesonide in mild and moderate chronic obstructive pulmonary disease: a randomised controlled trial. Lancet 1999;353: 1819-1823.

$\checkmark 9$ Pauwels RA, Lofdahl CG, Laitinen LA, Schouten JP, Postma DS, Pride NB, Ohlsson SV: Long-term treatment with inhaled budesonide in persons with mild chronic obstructive pulmonary disease who continue smoking. N Engl J Med 1999;340:1948-1953.
Burge PS, Calverley PMA, Jones PW, Spencer $\mathrm{S}$, Anderson JA, Maslen T: Randomised, double-blind, placebo-controlled study of fluticasone propionate in patients with moderate to severe chronic obstructive pulmonary disease: the ISOLDE trial. Br Med J 2000;320:1297-1303.

11 Lung Health Study Research Group: Effect of inhaled triamcinolone on the decline in pulmonary function in chronic obstructive pulmonary disease. New Engl J Med 2000;343: 1902-1909.

12 Paggiaro PL, Dahle R, Bakran I, Frith L, Hollingworth K, Efthimou J: Multicentre randomised placebo-controlled trial of inhaled fluticasone propionate in patients with chronic obstructive pulmonary disease. Lancet 1998;351:773-780.

13 Highland KB, Strange C, Heffner JE: Longterm effects of inhaled corticosteroids on FEV1 in patients with chronic obstructive pulmonary disease: a meta-analysis. Ann Intern Med 2003;138:969-973.

14 Sutherland ER, Allmers H, Ayas NT, Venn AJ, Martin RJ: Inhaled corticosteroids reduce the progression of airflow limitation in chronic obstructive pulmonary disease: a meta-analysis. Thorax 2003;58:937-941.

5 Sin DD, Wu L, Anderson JA, Anthonisen NR, Buist AS, Burge PS, Calverley PM, Connett JE, Lindmark B, Pauwels RA, Postma DS, Soriano JB, Szafranski W, Vestbo J: Inhaled corticosteroids and mortality in chronic obstructive pulmonary disease. Thorax 2005;60:992-997.

16 Calverley PM, Anderson JA, Celli B, Ferguson GT, Jenkins C, Jones PW, Yates JC, Vestbo J: Salmeterol and fluticasone propionate and survival in chronic obstructive pulmonary disease. N Engl J Med 2007;356:775789.

17 Celli BR, Thomas NE, Anderson JA, Ferguson GT, Jenkins CR, Jones PW, Vestbo J, Knobil K, Yates JC, Calverley PM: Effect of pharmacotherapy on rate of decline of lung function in chronic obstructive pulmonary disease: results from the TORCH study. Am J Respir Crit Care Med 2008;178:332-338.
18 Yang IA, Fong KM, Sim EH, Black PN, Lasserson TJ: Inhaled corticosteroids for stable chronic obstructive pulmonary disease. Cochrane Database Syst Rev 2007;CD002991.

19 Mahler DA, Wire P, Horstman D, Chang CN, Yates J, Fischer T, Shah T: Effectiveness of fluticasone propionate and salmeterol combination delivered via the Diskus device in the treatment of chronic obstructive pulmonary disease. Am J Respir Crit Care Med 2002;166:1084-1091.

20 Calverley P, Pauwels R, Vestbo J, Jones P, Pride N, Gulsvik A, Anderson J: Combined salmeterol and fluticasone in the treatment of chronic obstructive pulmonary disease: a randomoised controlled trial. Lancet 2003; 361:449-456.

21 Szafranski W, Cukier A, Ramirez A, Menga G, Sansores R, Nahabedian S, Peterson S, Olsson H: Efficacy and safety of budesonide/ formoterol in the management of chronic obstructive pulmonary disease. Eur Respir J 2003;21:74-81.

-22 Calverley PM, Boonsawat W, Cseke Z, Zhong $\mathrm{N}$, Peterson S, Olsson $\mathrm{H}$ : Maintenance therapy with budesonide and formoterol in chronic obstructive pulmonary disease. Eur Respir J 2003;22:912-919.

23 Kardos P, Wencker M, Glaab T, Vogelmeier $\mathrm{C}$ : Impact of salmeterol/fluticasone propionate versus salmeterol on exacerbations in severe chronic obstructive pulmonary disease. Am J Respir Crit Care Med 2007;175: 144-149.

$\checkmark 24$ Aaron SD, Vandemheen KL, Fergusson D, Maltais F, Bourbeau J, Goldstein R, Balter M, O’Donnell D, McIvor A, Sharma S, Bishop G, Anthony J, Cowie R, Field S, Hirsch A, Hernandez P, Rivington R, Road J, Hoffstein V, Hodder R, Marciniuk D, McCormack D, Fox G, Cox G, Prins HB, Ford G, Bleskie D, Doucette S, Mayers I, Chapman K, Zamel N, Fitzgerald M: Tiotropium in combination with placebo, salmeterol, or fluticasone-salmeterol for treatment of chronic obstructive pulmonary disease: a randomized trial. Ann Intern Med 2007;146:545-555. 
25 Nannini L, Cates C, Lasserson T, Poole P: Combined corticosteroid and long-acting beta-agonist in one inhaler versus long-acting beta-agonists for chronic obstructive pulmonary disease. Cochrane Database Syst Rev 2007;CD006829.

-26 Wedzicha JA, Calverley PM, Seemungal TA, Hagan G, Ansari Z, Stockley RA: The prevention of chronic obstructive pulmonary disease exacerbations by salmeterol/fluticasone propionate or tiotropium bromide. Am J Respir Crit Care Med 2008;177:19-26.

-27 Suissa S, Ernst P, Vandemheen KL, Aaron SD: Methodological issues in therapeutic trials of COPD. Eur Respir J 2008;31:927-933.

$\checkmark 28$ Suissa S: Lung function decline in COPD trials: bias from regression to the mean. Eur Respir J 2008;32:829-831.

29 La Vecchia C, Fabbri LM: Prevention of death in COPD. N Engl J Med 2007;356: 2211-2212.

30 Suissa S: Immortal time bias in pharmacoepidemiology. Am J Epidemiol 2008;167: 492-499.

-31 Suissa S: Observational studies of inhaled corticosteroids in chronic obstructive pulmonary disease: misconstrued immortal time bias. Am J Respir Crit Care Med 2006; 173:464-465.

- 32 Papi A, Romagnoli M, Baraldo S, Braccioni F, Guzzinati I, Saetta M, Ciaccia A, Fabbri LM: Partial reversibility of airflow limitation and increased exhaled NO and sputum eosinophilia in chronic obstructive pulmonary disease. Am J Respir Crit Care Med 2000; 162:1773-1777.

- 33 Brightling CE, Monteiro W, Ward R, Parker D, Morgan MD, Wardlaw AJ, Pavord ID: Sputum eosinophilia and short-term response to prednisolone in chronic obstructive pulmonary disease: a randomised controlled trial. Lancet 2000;356:1480-1485.

- 34 Siva R, Green RH, Brightling CE, Shelley M, Hargadon B, McKenna S, Monteiro W, Berry M, Parker D, Wardlaw AJ, Pavord ID: Eosinophilic airway inflammation and exacerbations of COPD: a randomised controlled trial. Eur Respir J 2007;29:906-913.

35 Ernst P, Baltzan M, Deschenes J, Suissa S: Low-dose inhaled and nasal corticosteroid use and the risk of cataracts. Eur Respir J 2006;27:1168-1174.

- 36 Hubbard R, Tattersfield A, Smith C, West J, Smeeth L, Fletcher A: Use of inhaled corticosteroids and the risk of fracture. Chest 2006; 130:1082-1088.

-37 Barnes PJ, Celli BR: Systemic manifestations and comorbidities of COPD. Eur Respir J 2009;33:1165-1185.

-38 Graat-Verboom L, Wouters EF, Smeenk FW, van den Borne BE, Lunde R, Spruit MA: Current status of research on osteoporosis in COPD: a systematic review. Eur Respir J 2009;34:209-218.
Scanlon PD, Connett JE, Wise RA, Tashkin DP, Madhok T, Skeans M, Carpenter PC, Bailey WC, Buist AS, Eichenhorn M, Kanner RE, Weinmann G: Loss of bone density with inhaled triamcinolone in Lung Health Study II. Am J Respir Crit Care Med 2004;170: 1302-1309.

40 Ferguson GT, Calverley PM, Anderson JA, Jenkins CR, Jones PW, Willits LR, Yates JC, Vestbo J, Celli B: Prevalence and progression of osteoporosis in patients with COPD: results from the TOwards a Revolution in COPD Health study. Chest 2009;136:14561465.

41 Crim C, Calverley PM, Anderson JA, Celli B, Ferguson GT, Jenkins C, Jones PW, Willits LR, Yates JC, Vestbo J: Pneumonia risk in COPD patients receiving inhaled corticosteroids alone or in combination: TORCH study results. Eur Respir J 2009;34:641-647.

- 42 Ernst P, Gonzalez AV, Brassard P, Suissa S: Inhaled corticosteroid use in chronic obstructive pulmonary disease and the risk of hospitalization for pneumonia. Am J Respir Crit Care Med. 2007;176:162-166.

43 Drummond MB, Dasenbrook EC, Pitz MW, Murphy DJ, Fan E: Inhaled corticosteroids in patients with stable chronic obstructive pulmonary disease: a systematic review and meta-analysis. JAMA 2008;300:2407-2416.

44 Singh S, Amin AV, Loke YK: Long-term use of inhaled corticosteroids and the risk of pneumonia in chronic obstructive pulmonary disease: a meta-analysis. Arch Intern Med 2009;169:219-229.

45 Keatings VM, Jatakanon A, Worsdell YM, Barnes PJ: Effects of inhaled and oral glucocorticoids on inflammatory indices in asthma and COPD. Am J Respir Crit Care Med 1997; 155:542-548.

46 Culpitt SV, Nightingale JA, Barnes PJ: Effect of high dose inhaled steroid on cells, cytokines and proteases in induced sputum in chronic obstructive pulmonary disease. Am J Respir Crit Care Med 1999;160:1635-1639.

47 Loppow D, Schleiss MB, Kanniess F, Taube C, Jorres RA, Magnussen H: In patients with chronic bronchitis a four week trial with inhaled steroids does not attenuate airway inflammation. Respir Med 2001;95:115-121.

-48 Hattotuwa KL, Gizycki MJ, Ansari TW, Jeffery PK, Barnes NC: The effects of inhaled fluticasone on airway inflammation in chronic obstructive pulmonary disease: a double-blind, placebo-controlled biopsy study. Am J Respir Crit Care Med 2002;165: 1592-1596

49 Bourbeau J, Christodoulopoulos P, Maltais F, Yamauchi Y, Olivenstein R, Hamid Q: Effect of salmeterol/fluticasone propionate on airway inflammation in COPD: a randomised controlled trial. Thorax 2007;62: 938-943.
50 Ito K, Lim S, Caramori G, Chung KF, Barnes PJ, Adcock IM: Cigarette smoking reduces histone deacetylase 2 expression, enhances cytokine expression and inhibits glucocorticoid actions in alveolar macrophages. FASEB J 2001;15:1100-1102.

51 Ito K, Ito M, Elliott WM, Cosio B, Caramori G, Kon OM, Barczyk A, Hayashi M, Adcock IM, Hogg JC, Barnes PJ: Decreased histone deacetylase activity in chronic obstructive pulmonary disease. New Engl J Med 2005; 352:1967-1976.

52 Barnes PJ: Role of HDAC2 in the pathophysiology of COPD. Ann Rev Physiol 2009;71: 451-464.

53 Ito K, Yamamura S, Essilfie-Quaye S, Cosio B, Ito M, Barnes PJ, Adcock IM: Histone deacetylase 2-mediated deacetylation of the glucocorticoid receptor enables NF-kB suppression. J Exp Med 2006;203:7-13.

54 Ito K, Tomita T, Barnes PJ, Adcock IM: Oxidative stress reduces histone deacetylase (HDAC) 2 activity and enhances IL-8 gene expression: role of tyrosine nitration. Biochem Biophys Res Commun 2004;315:240245 .

55 Osoata G, Yamamura S, Ito M, Vuppusetty C, Adcock IM, Barnes PJ, Ito K: Nitration of distinct tyrosine residues causes inactivation of histone deacetylase 2. Biochem Biophy Res Commun 2009;384:366-371.

56 Marwick JA, Caramori G, Stevenson CC, Casolari P, Jazrawi E, Barnes PJ, Ito K, Adcock IM, Kirkham PA, Papi A: Inhibition of PI3Kd restores glucocorticoid function in smoking-induced airway inflammation in mice. Am J Respir Crit Care Med 2009;179: 542-548.

57 Gamble E, Grootendorst DC, Hattotuwa K, O'Shaughnessy T, Ram FS, Qiu Y, Zhu J, Vignola AM, Kroegel C, Morell F, Pavord ID, Rabe KF, Jeffery PK, Barnes NC: Airway mucosal inflammation in COPD is similar in smokers and ex-smokers: a pooled analysis. Eur Respir J 2007;30:467-471.

58 Montuschi P, Collins JV, Ciabattoni G, Lazzeri N, Corradi M, Kharitonov SA, Barnes PJ: Exhaled 8-isoprostane as an in vivo biomarker of lung oxidative stress in patients with COPD and healthy smokers. Am J Respir Crit Care Med 2000;162:1175-1177.

59 Thomson NC, Chaudhuri R, Livingston E: Asthma and cigarette smoking. Eur Respir J 2004;24:822-833.

60 Ahmad T, Barnes PJ, Adcock IM: Overcoming steroid insensitivity in smoking asthmatics. Curr Opin Investig Drugs 2008;9:470477.

61 Barnes PJ, Adcock IM: Glucocorticoid resistance in inflammatory diseases. Lancet 2009;342:1905-1917.

62 Barnes PJ: Emerging pharmacotherapies for COPD. Chest 2008;134:1278-1286. 
63 Ito K, Lim S, Caramori G, Cosio B, Chung KF, Adcock IM, Barnes PJ: A molecular mechanism of action of theophylline: Induction of histone deacetylase activity to decrease inflammatory gene expression. Proc Natl Acad Sci USA 2002;99:8921-8926.

64 Cosio BG, Tsaprouni L, Ito K, Jazrawi E, Adcock IM, Barnes PJ: Theophylline restores histone deacetylase activity and steroid responses in COPD macrophages. J Exp Med 2004;200:689-695.

65 Marwick JA, Wallis G, Meja K, Kuster B, Bouwmeester T, Chakravarty P, Fletcher D, Whittaker PA, Barnes PJ, Ito K, Adcock IM, Kirkham PA: Oxidative stress modulates theophylline effects on steroid responsiveness. Biochem Biophys Res Commun 2008; 377:797-802.
66 Fox JC, Spicer D, Ito K, Barnes PJ, Fitzgerald MF: Oral or inhaled corticosteroid combination therapy with low dose theophylline reverses corticosteroid insensitivity in a smoking mouse model. Proc Am Thorac Soc 2007; 2:A637.

67 Cosio BG, Iglesias A, Rios A, Noguera A, Sala E, Ito K, Barnes PJ, Agusti A: Low-dose theophylline enhances the anti-inflammatory effects of steroids during exacerbations of chronic obstructive pulmonary disease. Thorax 2009;64:424-429.

8 Spears M, Donnelly I, Jolly L, Brannigan M, Ito K, McSharry C, Lafferty J, Chaudhuri R, Braganza G, Adcock IM, Barnes PJ, Wood S, Thomson NC: Effect of theophylline plus beclometasone on lung function in smokers with asthma: a pilot study. Eur Respir J 2009; 33:1010-1017.
69 Kirkham P, Rahman I: Oxidative stress in asthma and COPD: antioxidants as a therapeutic strategy. Pharmacol Ther 2006;111: 476-494.

70 Charron C, Sumakuza T, Oomura S, Ito K: EM-703, a non-antibacterial erythromycin derivative, restores HDAC2 activition diminished by hypoxia and oxidative stress. Proc Am Thorac Soc 2007; 175:A640.

71 Barnes PJ: Targeting histone deacetylase 2 in chronic obstructive pulmonary disease treatment. Expert Opin Ther Targets 2005; 9:1111-1121 